\title{
Crystallization conditions of kimberlite magma
}

\author{
Y. FEDORTCHOUK ${ }^{1 *}$, I.L. CHINN ${ }^{2}$ \\ ${ }^{1}$ Dalhousie University, Halifax, Canada B3H4R2 \\ (*correspondence: yana@dal.ca) \\ ${ }^{2}$ De Beers Exploration, Johannesburg, South Africa \\ (Ingrid.Chinn@debeersgroup.com)
}

Our knowledge of crystallization conditions of kimberlite magmas (temperature $(\mathrm{T})$, oxygen fugacity $\left(\mathrm{fO}_{2}\right)$ ) is limited by the uncertainty of the melt composition, significant alteration, mixed (xenocrystal and phenocrystal) nature of kimberlite minerals, and their exotic composition. Lack of robust constraints of $\mathrm{T}$ and $\mathrm{fO}_{2}$ leaves large uncertainties in understanding the emplacement processes especially for complex kimberlite pipes with diatreme Kimberley-type pyroclastic kimberlite (KPK) that form the largest diamond deposits. We tackle this problem by integrating results from independent approaches to examine variation of crystallization conditions inside complex kimberlite pipes.

We use BK/1 pipe from the Orapa cluster (Botswana) that comprises three distinct kimberlite facies: two coherent kimberlites (CK-A and CK-B) and volcaniclastic kimberlite (MVK). Samples from three drillholes provide depth profiles down to $200 \mathrm{~m}$ depth in each of the facies. Previous study of diamond resorption features demonstrated the increasing role of magmatic fluid from CK-B to CK-A to MVK facies. Here we confirmed this trend with $\mathrm{Sr}$ vs. REE composition of apatite. Abundant perovskite in CK-B and MVK facies allows use of the Fe-in perovskite oxybarometer giving $\mathrm{fO}_{2}$ values -2.5 to -5 relative to $\mathrm{Ni}-\mathrm{NiO}$ buffer (NNO) compatible with $\mathrm{fO}_{2}$ values determined from chromite inclusions in fresh olivine rims from Lac de Gras kimberlites, Canada. $\mathrm{FO}_{2}$ shows $>1 \log$ unit increase from CK-B to MVK facies and 1 log unit change with depth in CK-B. Compositions of the reaction rims around ilmenite macrocrysts record changes in the activity of $\mathrm{SiO}_{2}$ and $\mathrm{CO}_{2}$ in the melt and show evolution from magnetite - perovskite - wollastonite in CK-B to magnetite - rutile in CK-A and magnetite - rutile in MVK. Co-existence of perovskite with titanite in a limited depth range fixes silica activity in this portion of the kimberlite system. Independent methods used in this study give consistent indications of the presence/absence of magmatic fluid, and $\mathrm{T}-\mathrm{fO}_{2}$ estimates. We use the observed variation of these parameters between the different kimberlite facies and the depth in the kimberlite pipe to model the emplacement processes of a large complex kimberlite pipe with KPK diatreme facies. 